ZOOLOGIA 30 (4): 371-378, August, 2013

http://dx.doi.org/10.1590/S1984-46702013000400002

\title{
Life cycle of Agrotis malefida (Lepidoptera: Noctuidae): a diapausing cutworm
}

\author{
Alexandre Specht ${ }^{1,5}$, Andrés O. Angulo², Tania S. Olivares², Edegar Fronza ${ }^{3}$, Vânia F. \\ Roque-Specht ${ }^{4}$, Eduardo Valduga ${ }^{3}$, Francine Albrecht ${ }^{3}$, Graziela Poletto ${ }^{3} \&$ Neiva M. Barros ${ }^{3}$
}

\author{
${ }^{1}$ Laboratório de Entomologia, Embrapa Cerrados. Caixa Postal 08223, 73310-970 Planaltina, DF, Brazil. \\ ${ }^{2}$ Departamento de Zoología, Facultad de Ciencias Naturales y Oceanográficas, Universidad Concepción. Casilla 160-C, \\ Concepción, Chile. \\ ${ }^{3}$ Instituto de Biotecnologia, Universidade de Caxias do Sul. Caixa Postal 1352, 95070-560 Caxias do Sul, RS, Brazil. \\ ${ }^{4}$ Faculdade UnB Planaltina. Área Universitária 1, Vila Nossa Senhora de Fátima, 73300-000 Planaltina, DF, Brazil. \\ ${ }^{5}$ Corresponding author. E-mail: alexandre.specht@embrapa.br
}

\begin{abstract}
This study describes the life cycle of Agrotis malefida Guenée, 1852 (Noctuidae: Noctuinae) under laboratory conditions. The insects were reared in a controlled environment $\left(25 \pm 1{ }^{\circ} \mathrm{C}, 70 \pm 10 \% \mathrm{RH}\right.$ and 14 hours photo phase) and observed daily. The larvae were fed Greene's artificial diet and adults were offered a $10 \%$ sucrose solution. The viability and duration of immature stages were assessed. The experiment initiated with 2,410 eggs. Larvae were isolated shortly after hatching. Longevity, pre-, post- and oviposition, fecundity and fertility of 13 adult couples were also evaluated. The viability of eggs, larvae, pupae and pre-pupae was $96.72,91.25,78.37$ and $95.26 \%$, respectively. The average duration of egg, larva, pre-pupa, pupa and adult was 7.93, 54.26, 61.61, 37.43 and 12.85 days, respectively. The immature stage of A. malefida lasted an average of 161.29 days, ranging from 102 to 227 days. The life cycle of $A$. malefida is much longer than that of congeners. The mean fecundity was 1,696.77 eggs and fertility 1,641.15 larvae per female. Under the conditions in which the study was conducted, the biotic potential of A. malefida was of $606,666.59$ individuals/female/ year. The results also indicated that this species goes through larval (pre-pupae) and pupal diapause.
\end{abstract}

KEY WORDS. Bionomy; caterpillar; development; diapause.

Agrotis Ochsenheimer, 1816 (Noctuidae: Noctuinae: Noctuini) (LAFONTAINE \& SCHMIDT 2010) is a cosmopolitan genus with 317 species (Poole 1989). All Agrotis larvae are voracious and are able to feed on a variety of hosts (Kitching \& Rawlins 1998, Pogue 2006). They have underground habits, coming to the surface at night to feed. While feeding, they cut the stems of their food plants, causing severe damage and rapid crop loss. When disturbed, Agrotis larvae roll up in a very characteristic behavior (Baudino 2004, Lafontaine 2004, Angulo et al. 2008).

Agrotis malefida Guenée, 1852 has been recorded from most of the Americas (Pastrana \& Hernandes 1979, Rizzo et al. 1995, LAFONTAINE 2004) and is likely to occur worldwide (ANGULO \& QuezADA 1975). The species has been widely documented in the United States and Mexico (Lafontaine 2004, Pogue 2006), Chile (Angulo \& Quezada 1975, Angulo et al. 2008), Argentina (Margheritis \& Rizzo 1965, Igarzábal et al. 1994, Rizzo et al. 1995, Baudino 2004, Pastrana 2004), Brazil (Silva et al. 1968, Specht \& Corseuil 1996, 2002, Specht et al. 2004) and Uruguay (Bentancourt \& SCatoni 2006). Larvae of $A$. malefida are known in North America as Pale-Sided Cutworms; in Latin America as "gusano áspero", "oruga áspera" or "oruga cortadora áspera" (LAFontaine 2004); and in Brazil as "lagarta-rosca" (Silva et al. 1968).
Larvae of $A$. malefida are polyphagous, attacking various herbaceous, native and cultivated plants, including economically relevant crops such as alfalfa, barley, bean, beet, cabbage, cauliflower, clover, coffee, collard, corn, cotton, cowpea, cucumber, flax, garlic, lettuce, melon, oat, onion, pea, pepper, potato, rice, rye, sorghum, soybean, squash, strawberry, sunflower, Swiss chard, tobacco, tomato and wheat (SIIVA et al. 1968, Villata et al. 1988, CotTo et al. 1995, Rizzo et al. 1995, Pastrana 2004, Specht et al. 2004, Baudino \& Villarreal 2007, Angulo et al. 2008). Larvae often build a subterranean tunnel which is used as a hiding place during the day, and as a place to eat the host plants cut during the night (LAFONTAINE 2004).

The economic relevance of $A$. malefida has motivated various studies on the morphology of the adult (ANGULO \& Quezada 1975) and of immature stages (Rizzo et al. 1995, ANGUlo et al. 2008), along with biological studies (VIlLATA et al. 1988, Rizzo et al. 1995, Baudino 2004, Baudino \& Villarreal 2007). Despite the morphological similarities of the adults and the sympatry of Agrotis ipsilon (Hufnagel, 1766) and A. malefida in the American continent (ANgulo \& Quezada 1975), previous studies indicate several biological differences, especially in the immature stages of A. malefida (Villata et al. 1988, Rizzo et al. 1995, Baudino 2004, Baudino \& Villarreal 2007). In view of the 
importance of the species, and its large intraspecific variability (Villata et al. 1988, Rizzo et al. 1995), we have endeavored to describe the biological parameters and to estimate the biotic potential of $A$. malefida in the laboratory, using individual observations on thousands of specimens.

\section{MATERIAL AND METHODS}

Our laboratory rearing experiment initiated with 13 couples obtained from a mass rearing colony maintained by the Laboratório de Biologia, Campus Universitário da Região dos Vinhedos (CARVI), Universidade de Caxias do Sul (UCS). The mass rearing itself originated from individuals collected in the Vale dos Vinhedos, Bento Gonçalves, state of Rio Grande do Sul. Our experiments were conducted in a controlled environment $\left(25 \pm 1^{\circ} \mathrm{C}, 70 \pm 10 \%\right.$ UR and 14 hours photo phase), with daily observations.

Each adult couple $(n=13)$ was maintained inside a cylindrical plastic container (10 cm diameter, $15 \mathrm{~cm}$ height). In order to stimulate oviposition, strings of filter-paper of the same length as the plastic vial were inserted into each container and attached using a plastic film cover. The moths were fed an aqueous sucrose solution (10\%), made available in hydrophilic cotton inside a $10 \mathrm{~mL}$ glass Erlenmeyer flask. The following parameters were evaluated: fecundity (number of eggs per female), fertility (number of hatched larvae per female), longevity and duration of pre-oviposition, post-oviposition and oviposition periods.

During the egg stage, we assessed the viability and duration of the incubation period of five random ovipositions from each couple (including first and last ovipositions), totaling 2,410 eggs. Each egg mass was individually placed in a Petri dish, where it remained until the larvae hatched. The bottom of each Petri dish was lined using filter paper moistened with distilled water, in order to avoid desiccation.

After hatching, neonate larvae were separately placed in $150 \mathrm{ml}$ plastic cups, covered with a lid, and fed an artificial diet (GREENE et al. 1976), previously used successfully by Rizzo et al. (1995) for the same species. We evaluated the survival and the duration of the larval period of 2,331 individuals. The pre-pupal period was considered separately, and its onset was recorded when the larva stopped feeding and decreased in size. We added expanded vermiculite, moistened with distilled water, to each cup, in order to allow the pre-pupae to build a pupal chamber.

Pupae were kept in the same containers as pre-pupae. On the second day after pupation, when the cuticle had hardened, we ascertained the sex of each individual using sketches from ANGulo et al. (2008). Besides ascertaining the duration of the pupal period, we measured the weight, the greater width between pterotecae, and the total length of each pupa.

We calculated the biological potential from the biological variables, considering the environmental resistance to be null. The fertility life table was calculated using the equations of
Silveira Neto et al. (1976) and the following parameters were determined: net reproductive rate (Ro), mean generation time (T), natural intrinsic growth rate $(\mathrm{rm})$, and infinite growth rate $(\Lambda)$.

Monthly collections of $A$. malefida moths were made within the CARVI $\left(29^{\circ} 08^{\prime} 99^{\prime \prime} S ; 5^{\circ} 31^{\prime} 39^{\prime \prime} \mathrm{W}, 675 \mathrm{~m}\right.$ a.s.l.), from January 2007 to December 2008, four nights during each new moon, using light traps as described in SPEcht et al. (2005), in order to obtain information on the period of adult occurrence.

The temporal and morphometric parameters were analyzed using descriptive statistics to calculate the means and standard errors. When necessary, the means were compared using a t-test assuming unequal variances, at a significance level of $95 \%$.

Voucher specimens (10 couples) were deposited in the collection of the CARVI-UCS.

\section{RESULTS}

\section{Adult stage}

The longevity of $A$. malefida did not significantly differ between the sexes $(p=0.076)$, and represented $7.38 \%$ of the developmental cycle (Fig. 1, Table I). Under the conditions of this study, adults of $A$. malefida reach sexual maturation soon after emergence (Table II). The egg laying period occurs from the second to the tenth day after sexual maturation, and the highest fecundity was observed between the seventh and the tenth day (Fig. 2). The fecundity of A. malefida varied greatly between individuals resulting in approximately 1,700 eggs per female (Table II).

Table I. Survival and duration of the life cycle of Agrotis malefida during different stages of development, under controlled conditions ( $25 \pm 1{ }^{\circ} \mathrm{C}, 70 \pm 10 \% \mathrm{RH}$ and 14 hours photo phase).

\begin{tabular}{lcccc}
\hline $\begin{array}{c}\text { Developmental } \\
\text { stage }\end{array}$ & Inicial-final N & $\begin{array}{c}\text { Survival } \\
(\%)\end{array}$ & $\begin{array}{c}\text { Duration } \\
\text { (days) }\end{array}$ & Range \\
\hline Adult & 26 & - & $12.85 \pm 3.78$ & $5-22$ \\
Egg & $2,410-2,331$ & 96.72 & $7.93 \pm 1.22$ & $6-10$ \\
Larvae & $2,331-2,127$ & 91.25 & $54.25 \pm 6.39$ & $44-77$ \\
Pre-pupae & $2,127-1,667$ & 78.37 & $61.61 \pm 17.56$ & $10-131$ \\
Pupae & $1,667-1,588$ & 95.26 & $37.43 \pm 4.13$ & $11-99$ \\
Total immature & 1,588 & - & $161.29 \pm 17.35$ & $102-227$ \\
\hline Total & - & 65.89 & 174.08 & - \\
\hline
\end{tabular}

Table II. Mean fecundity and duration of the pre-, post-, and oviposition periods (days) of Agrotis malefida reared under controlled conditions $\left(25 \pm 1{ }^{\circ} \mathrm{C}, 70 \pm 10 \% \mathrm{RH}\right.$ and 14 hours photo phase). ( $\mathrm{N}=13$ couples).

\begin{tabular}{lcc}
\hline \multicolumn{1}{c}{ Parameter } & Mean \pm SE & Range \\
\hline Fecundity (eggs/female) & $1696.77 \pm 412.73$ & $992-2170$ \\
Periods (days) & & \\
Pre-ovipostion & $2.54 \pm 1.05$ & $1-4$ \\
Post-ovipostion & $0.15 \pm 0.38$ & $0-1$ \\
Oviposition & $9.69 \pm 3.04$ & $5-15$ \\
\hline
\end{tabular}




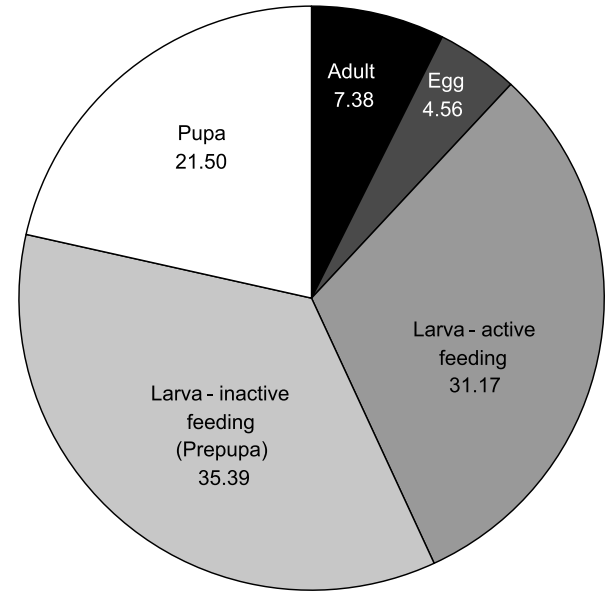

Figure 1. Duration (\%) of each developmental period for Agrotis malefida reared at $25 \pm 1{ }^{\circ} \mathrm{C}, 70 \pm 10 \% \mathrm{RH}$ and 14 hours photo phase.

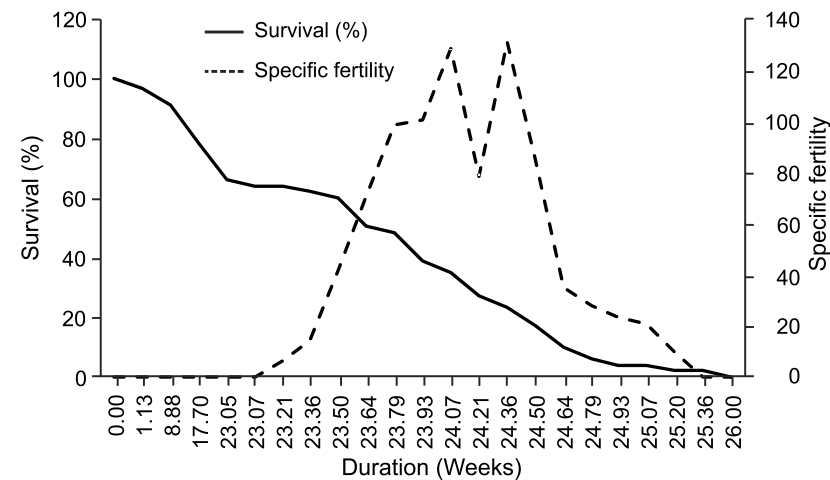

Figure 2. Relationship between specific fertility $(\mathrm{mx})$ and survival rate (Ix) during the development of Agrotis malefida reared on an artificial diet at $25 \pm 1{ }^{\circ} \mathrm{C}, 70 \pm 10 \% \mathrm{RH}$ and 14 hours photo phase.

Adults of $A$. malefida were collected during most of the year, except in November and December, with the largest numbers being collected between April and July (Fig. 3).

\section{Egg stage}

The average duration of the embryonic period corresponded to $4.557 \%$ of the life cycle (Fig. 1, Table I). We observed a high viability of $A$. malefida eggs (Table I), including those from the first oviposition.

\section{Larval stage}

In our experiment, the average duration of the larval stage (including the pre-pupa) of $A$. malefida was almost four months (Table I), accounting for two-thirds of the entire life cycle (Fig. 1).

Females spent more time in the larval stage than males (Table III). Despite the large difference between sexes in the duration of the larval period, not including the pre-pupal period, the variation in the duration of this phase was similar,

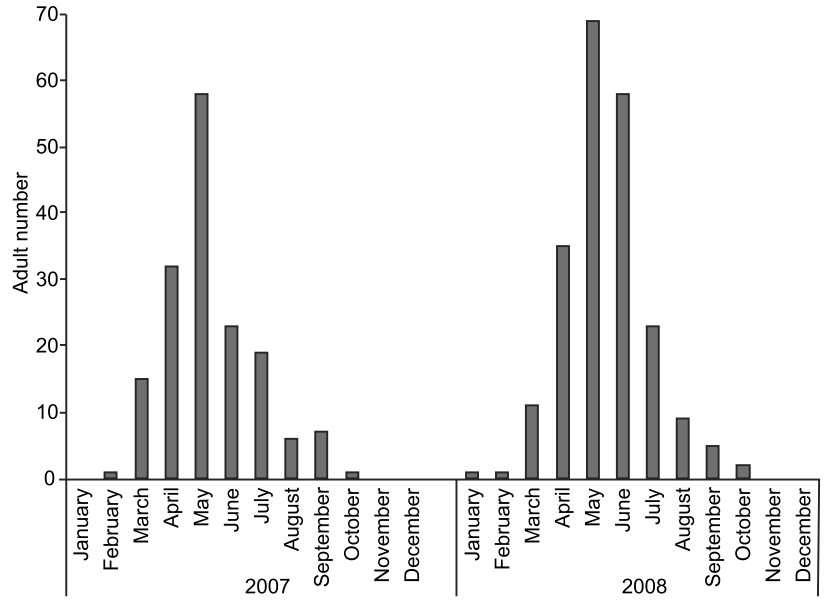

Figure 3. Number of Agrotis malefida adults collected by light traps, during four nights per month, in the Bento Gonçalves municipality, state of Rio Grande do Sul, Brazil.

and did not exceed 33 days for either sex (Table III). Most females $(81.43 \%)$ developed between 40 and 59 days, and only 41 (5.04\%) took longer than 70 days (Table IV). Similarly, most males $(74.06 \%)$ completed their larval phase between 50 and 59 days, and only 30 individuals (3.89\%) took more than 70 days.

Table III. Agrotis malefida reared under controlled conditions $(25 \pm$ $1{ }^{\circ} \mathrm{C}, 70 \pm 10 \% \mathrm{RH}$ and 14 hours photophase). Mean duration (days), and standard errors, of larval and pupal periods, considering males and females separately. The prepupal period is separated from the larval period. The mean values of both sexes were compared using a t-test, at a confidence level of $95 \%$.

\begin{tabular}{lccccc}
\hline & \multicolumn{2}{c}{ Females $(\mathrm{n}=813)$} & & \multicolumn{2}{c}{ Males $(\mathrm{n}=775)$} \\
\cline { 2 - 3 } \cline { 5 - 6 } & Mean \pm SE & Range & & Mean \pm SE & Range \\
\hline Larvae & $54.77 \pm 6.64^{*}$ & $44-77$ & & $53.70 \pm 6.05$ & $46-77$ \\
Pre-pupae & $62.23 \pm 17.28 \mathrm{~ns}$ & $10-128$ & & $60.93 \pm 17.83$ & $18-131$ \\
Pupae & $37.78 \pm 4.24^{*}$ & $16-99$ & & $37.05 \pm 3.98$ & $11-71$ \\
\hline Total $^{*}$ & $162.81 \pm 17.34^{*}$ & $117-227$ & & $159.68 \pm 17.23$ & $102-225$ \\
\hline${ }^{*} \mathrm{p}<0.001, \mathrm{~ns}=\mathrm{p}>0.05$ & & & & &
\end{tabular}

The duration of the pre-pupal period of $A$. malefida was longer for females (without statistical significance) than for males (Table III) and was greatly variable (Table IV). The highest frequencies (above 15\%) of males and females which completed the pre-pupal period occurred between 40 and 80 days. A few pre-pupae were observed between days 0-20 ( $\mathrm{n}=4 \sim$ $0.25 \%)$, and also after day $100(\mathrm{n}=32 \sim 2.02 \%)$ (Table IV). The regression analysis $\left(\mathrm{n}=1,583, \mathrm{r}^{2}=0.066, \mathrm{p}<0.001\right)$ indicated a direct correlation between the number of days a larva remained active, and the duration of the pre-pupal stage. 
Table IV. Number of immature females and males of Agrotis malefida, at ten day intervals, indicating larval feeding activity, pre-pupae and pupae, maintained under controlled conditions $\left(25 \pm 1{ }^{\circ} \mathrm{C}, 70 \pm 10 \% \mathrm{RH}\right.$ and 14 hours photo phase).

\begin{tabular}{|c|c|c|c|c|c|c|c|c|c|c|c|c|}
\hline \multirow{4}{*}{$\begin{array}{l}\text { Interval } \\
\text { (days) }\end{array}$} & \multicolumn{8}{|c|}{ Larvae } & \multicolumn{4}{|c|}{ Pupae } \\
\hline & \multicolumn{4}{|c|}{ Active feeding } & \multicolumn{4}{|c|}{ Inactive feeding (prepupae) } & & & & \\
\hline & \multicolumn{2}{|c|}{ Female } & \multicolumn{2}{|c|}{ Male } & \multicolumn{2}{|c|}{ Female } & \multicolumn{2}{|c|}{ Male } & \multicolumn{2}{|c|}{ Female } & \multicolumn{2}{|c|}{ Male } \\
\hline & $\mathrm{N}$ & $\%$ & $\mathrm{~N}$ & $\%$ & $\mathrm{~N}$ & $\%$ & $\mathrm{~N}$ & $\%$ & $\mathrm{~N}$ & $\%$ & $\mathrm{~N}$ & $\%$ \\
\hline $10-19$ & - & - & - & - & 1 & 0.12 & 3 & 0.39 & 3 & 0.37 & 3 & 0.39 \\
\hline $20-29$ & - & - & - & - & 13 & 1.60 & 22 & 2.84 & 5 & 0.62 & 5 & 0.64 \\
\hline $30-39$ & - & - & - & - & 59 & 7.26 & 49 & 6.32 & 579 & 71.22 & 611 & 78.84 \\
\hline $40-49$ & 190 & 23.37 & 92 & 11.87 & 143 & 17.59 & 166 & 21.42 & 222 & 27.31 & 151 & 19.48 \\
\hline $50-59$ & 473 & 58.18 & 574 & 74.07 & 144 & 17.71 & 133 & 17.16 & - & - & 2 & 0.26 \\
\hline $60-69$ & 109 & 13.41 & 76 & 10.19 & 178 & 21.89 & 161 & 20.77 & 3 & 0.37 & 1 & 0.13 \\
\hline $70-79$ & 41 & 5.04 & 30 & 3.87 & 148 & 18.20 & 124 & 16.00 & - & - & 2 & 0.26 \\
\hline $80-89$ & - & - & - & - & 85 & 10.46 & 79 & 10.19 & - & - & - & - \\
\hline $90-99$ & - & - & - & - & 27 & 3.32 & 21 & 2.71 & 1 & 0.12 & - & - \\
\hline 100-109 & - & - & - & - & 7 & 0.86 & 11 & 1.42 & - & - & - & - \\
\hline $120-129$ & - & - & - & - & 1 & 0.12 & 1 & 0.13 & - & - & - & - \\
\hline 130-139 & - & - & - & - & - & - & 1 & 0.13 & - & - & - & - \\
\hline Total & 813 & 100.00 & 775 & 100.00 & 813 & 100.00 & 775 & 100.00 & 813 & 100.00 & 775 & 100.00 \\
\hline
\end{tabular}

Despite our precautions, $28.48 \%$ of the larvae died in our experiment, with higher mortality $(71.19 \%)$ of the larval stage being observed during the pre-pupal period (Table I).

\section{Pupal stage}

The pupal stage of A. malefida accounted for $21.501 \%$ of the development cycle (Fig. 1, Table I) However, the variation in the duration of this stage was very large, where $98.423 \%$ of specimens had a larval period lasting from 31 to 50 days and the others lasted from 11 to 99 days (Tables I, III and IV).

The survival of $A$. malefida pupae was relatively high (Table I). The female pupae were significantly larger and heavier than their male counterparts (Table V).

Table V. Weight, width and length of Agrotis malefida pupae (means and standard errors), reared under controlled conditions ( $25 \pm 1{ }^{\circ} \mathrm{C}, 70 \pm 10 \% \mathrm{RH}$ and 14 hours photo phase), including comparisons on females and males using a t-test, at a confidence level of $95 \%$.

\begin{tabular}{lccc}
\hline & Weight $(\mathrm{g})$ & Width $(\mathrm{mm})$ & Length $(\mathrm{mm})$ \\
\hline Females $(\mathrm{n}=194)$ & $0.89 \pm 0.15$ & $8.04 \pm 0.51$ & $26.39 \pm 1.80$ \\
Males $(\mathrm{n}=131)$ & $0.81 \pm 0.11$ & $7.68 \pm 0.42$ & $25.92 \pm 1.56$ \\
& $* *$ & $* *$ & $*$ \\
\hline
\end{tabular}

${ }^{*} p<0.01,{ }^{* *} p<0.001$

\section{Biotic potential}

The sex ratio (sr) calculated for the 1,588 pupae (813 females and 775 males) was 0.512 . Each female oviposited, on average, 1,696.769 eggs; the overall egg survival was $65.892 \%$, yielding 1,118.035 viable individuals per female (d). The average duration of the life cycle (174.075 days) corresponded to
2.097 generations per year (n). Thus, considering the environmental resistance (er) as null, we obtained the following result for the equation $\mathrm{BP}=\left(\mathrm{sr}^{*} \mathrm{~d}\right)^{\mathrm{n}}-\mathrm{er} \therefore \mathrm{BP}=(0.512 \times 1118.035)^{2.097}$ $-0=6.067 \times 10^{5}$ individuals per female. In other words, each female could generate more than half a million offspring.

\section{Life and fertility tables}

The net reproductive rate (Ro) was 322.6 times per generation, and the mean generation time (T) was 23.97 weeks. The intrinsic rate of increase $(\mathrm{rm})$ was 0.24 , with a finite rate of increase $(\Lambda)$ - the number of females added to the population per female that will generate another female - of 1.27. The maximum rates of population increase occurred between days 168 and 170 , during the $24^{\text {th }}$ week of development (Fig. 2).

\section{DISCUSSION}

\section{Adult stage}

In our experiment, the longevity of A. malefida (Table I) was higher than in the results obtained by VILLATA et al. (1988) (4.86 days) and Rizzo et al. (1995) (3-9 days). When reared at temperatures near those used in our experiment, the longevity of the congener $A$. ipsilon was equivalent to that of $A$. malefida (BENTo et al. 2007 13 days). However, in our experiment, $A$. malefida spent more time in the larval stage $(66.56 \%$ - Fig. 1) with respect to A. ipsilon individuals (SANTOS \& NAKANO $1982 \sim 24.3 \%$, BENTO et al. 2007 24.5\%), which spent relatively more time in the adult stage.

The relatively short pre-oviposition period (Table II) indicates that, under the conditions of this study, adults of $A$. malefida reach sexual maturation soon after emergence. Females of $A$. malefida, as those of $A$. ipsilon, are able to lay eggs two 
days after emergence (HARRIs et al. 1962, SWIER et al. 1976, SANTOS \& NaKano 1982, Bento et al. 2007). The duration of the egg laying period and the highest fecundity, between the seventh and the tenth day (Fig. 2), also resemble the values obtained for A. ipsilon (Harris et al. 1962, SwiER et al. 1976, SANTOS \& NAKANO 1982, Bento et al. 2007).

The mean fecundity of $A$. malefida (Table II) resembles that obtained by Rizzo et al. (1995), who reported between 1,000 and 1,600 eggs per female. However, it differs from the results of VILLATA et al. (1988), who reported an average of only 474.5 eggs per fertile female. Our results are also consistent with values obtained for other Noctuinae, such as for A. ipsilon (Swier et al. 1976 - 1,423.53, ARCHER et al. 1980 - maximum average 1,984, SANTOS \& NAKANO 1982 - 1,263, Bento et al. 2007 - 1,806 eggs), Agrotis ignicans (Guenée, 1852) (Foester \& Mello 1996 - 1,807) and Agrotis mahalpa Schaus, 1898 (SРесHT et al. 2008 - 2,014).

Despite the greater abundance of individuals per collection, our field results resembled observations made by TARRAGÓ et al. (1975), in Santa Maria, Rio Grande do Sul, and by S. Silveira Neto (unpublished data) in various localities of São Paulo, indicating collections of adults during virtually all the year, with highest numbers between April and June. On the other hand, the same species is only reported from April to July in south and southeastern Rio Grande do Sul by SPECHT et al. (2004). Similar behavior is recorded in various localities of Argentina with a population peak in April (Rizzo et al. 1995, BAUDINo 2004, Baudino \& VilLaRreal 2007). Such data indicate that despite being considered a univoltine species (Villata et al. 1988, Rizzo et al. 1995, BENTANCOURT \& SCATONI 2006), under field conditions adults of $A$. malefida may emerge at different times of the year, peaking in winter. Similar flight behavior is recorded in the northern part of USA where adults begin emerging in late January (Lafontaine 2004). Nevertheless, A. malefida flies throughout the year in the southern United States (Lafontaine 2004) and within the xerophilic zone in the island of Guadeloupe (ZAGATTI et al. 2006).

These observations indicate that in higher latitudes larvae of $A$. malefida are sensitive to the daily increase of the photoperiod culminating in aestival diapause, a mechanism described for several insects, especially from temperate regions (SCHNEIDER 2009). In fact, despite the non-variable photoperiod used in our experiment (14 hours of light), it corresponded to the maximum observed at latitude $30^{\circ}$, which triggered the initiation of diapause, at least in part of the population.

\section{Egg stage}

The embryonic period (Table I) of $A$. malefida was longer than previously reported by Rizzo et al. (1995), who found that this stage lasts five to six days under lower temperatures (22$23^{\circ} \mathrm{C}$ ). Our results, however, resemble those of Villata et al. (1988), who reported that the embryonic period in A. malefida lasted eight days when experiments were conducted at $25^{\circ} \mathrm{C}$ and a relative humidity of $60 \%$. The embryonic period of $A$. malefida is relatively long when compared with that of several other representatives of Noctuini reared under similar temperatures, such as in A. ipsilon (HarRIs et al. $1962-4$ days, SANTOS \& NAKANo 1982 - 4 days, Bento et al. 2007 - 3.3 days) and Agrotis infecta (Ochsenheimer, 1816) (Teston et al. 2001 - 3.2 days).

The high viability of $A$. malefida eggs (Table I), including those from the first oviposition, suggests that females were fertilized soon after emergence. These results differ from those obtained for $A$. ipsilon females, which are less attractive to males during the first few days after emergence (SWIER et al. 1976), resulting in infertile first ovipositions, and consequently low average values of relative viability (SANTOS \& NAKANO 1982 to $64.45 \%$, Bento et al. 2007 to $81.00 \%$ ).

\section{Larval stage}

In our experiment, the long duration of the larval stage (including the pre-pupa) of A. malefida was similar to the 93.2 days reported for the same species when reared at $25^{\circ} \mathrm{C}$ and $60 \%$ humidity, but very different from the 36.14 days found for specimens reared under the same temperature and 50\% relative humidity (VILlaTA et al. 1988). In the present study, larvae remained in separate plastic cups inside an incubator with a relative humidity of $70 \pm 10 \%$. They were fed an artificial diet rich in water. After the third or fourth instars, larvae dug a tunnel in their food, where they remained. Therefore, the effective experimental humidity was above 50 and $60 \%$ used by Villata et al. (1988) and the added moisture was likely responsible for increasing the duration of the larval phase. The direct relationship between increased moisture and increased duration of the larval period in A. malefida (VILlata et al. 1988) contrasts with results described for $A$. ipsilon. Moisture generally did not influence the duration of the developmental phases of A. ipsilon, except during the first five instars, when it significantly accelerates the larval stage (ArCHER et al. 1980).

The larval stage of $A$. malefida, corresponding to $66.56 \%$ of the species' entire life cycle, lasted longer than in other Noctuini representatives such as A. ipsilon (HarRIs et al. $1962-$ 48.99\%; Santos \& Nakano 1982 - 43.42\%, Bento et al. 2007 46.65\%), Peridroma saucia (Hübner, [1808]) (Moreno Fajardo \& Serna Cardona $2006-43.15 \%)$, A. infecta (Teston et al. 2001 44.09\%) and A. mahalpa (S Pеснт et al. 2008 - 48.18\%). Furthermore, the larval phase of $A$. malefida showed greater variability (Tables I and III), a fact that had also been mentioned by Villata et al. (1988) and Rizzo et al. (1995), though to a lesser extent. However, the period in which the larvae are active and feeding (Table I, Fig. 1) (31.17\%) is similar among A. malefida and A. ipsilon (Harris et al. $1962-45.37 \%$, SANTos \& NaKano 1982 - 38.82\%), P. saucia (Moreno Fajardo \& Serna Cardona 2006 -40.06\%), A. infecta (Teston et al. $2001-37.48 \%$ ) and A. mahalpa (SPECHT et al. $2008-42.14 \%$ ).

The longer larval period of $A$. malefida females (Table III) can be explained by the fact that females are on average larger (see pupal stage). For this reason, in species which are sexually dimorphic such as Spodoptera albula (Walker, 1857) (Noctuidae: Noctuinae: Prodeniini) (Montezano et al. 2013) and in other 
Lepidoptera, females can have additional instars (Allen et al. 2011).

The great variation of the pre-pupal period (Table IV) can be considered a specific characteristic of A. malefida, already described for Lepidoptera of temperate regions in which individuals in the population emerge at different times (SCHNeIder 2009). Additionally, A. malefida males are smaller, have faster development during larval and pupal periods, emerging before the females as a form of sexual competition (Allen et al. 2011), like other species of the same group, such as Sesamia nonagrioides (Lefebvre, 1827) (López et al. 2003).

After rearing the same species under four different temperature regimes and humidity between 50 and 60\%, Villata et al. (1988) found that individuals remained in the pre-pupal stage between 3-25 days. However, in their study the last instar (presumably the pre-pupa) lasted longer on average when temperatures were set between 19 and $25^{\circ} \mathrm{C}$ and the relative humidity was highest. Their results corroborate our findings that higher humidity levels lengthen the larval period of $A$. malefida. The occurrence of prepupal diapause in $A$. malefida (Bentancourt \& SCATONi 2006) has already been reported for some noctuid species in other genera, such as in Xestia c-nigrum (Linnaeus, 1758) (НоNік 1979, ОкU 1984), Helicoverpa armigera (Hübner, [1809]) (WiLSON et al. 1979, QURESHI et al. 2000, Feng et al. 2010), and S. nonagrioides (FAnTINOU et al. 1996, GadenNne et al. 1997, EizAguirre et al. 2008). However, larval and pupal diapause were not expected to occur in $A$. malefida under the rearing conditions of our experiment $\left(25 \pm 1^{\circ} \mathrm{C}, 70 \pm 10 \% \mathrm{RH}\right.$ and 14 hours photoperiod). Nevertheless, EIzAguirre et al. (2008) mention a few individuals of $S$. nonagrioides expressing diapause when reared under similar environmental conditions.

The direct correlation between the number of days a larva remained active and the duration of the prepupal stage may be related to the number of larval instars. Even though we have not investigated the number of larval instars of our specimens, Villata et al. (1988) reported that A. malefida may have from seven to 11 instars. Additionally, according to them, the greater number of instars occurs when the larval phase is longer. In view of the fact that the number of instars is greater in noctuids that undergo diapause (EsPerk et al. 2007, GADENNE et al. 1997), and given the results found in our study combined with those of Villata et al. (1988), we have confirmed that A. malefida larvae undergo larval diapause.

The lower larval survival rate of $A$. malefida, especially in the prepupal stage (Table I), may be associated with the longer duration of the larval period in this species. A similar observation was made by EIZAGuirRe et al. (2008), who noted that diapausing larvae of $S$. nonagrioides had low survival rates.

\section{Pupal stage}

In this study, the variation in the duration of the pupal stage of A. malefida (Tables I, III and IV) was much higher than the range reported for the same species by Rizzo et al. (1995) (29 to 44 days) and Baudino (2004) (41.0 \pm 20 days). These re- sults demonstrate that, like other noctuids such as $H$. armigera (Wilson et al. 1979, QURESH et al. 2000), the pupa of A. malefida may also go through diapause.

The high survival of $A$. malefida pupae (Table I) was similar to that of most noctuids reared in the laboratory, such as $A$. ipsilon (ReEse et al. 1972, BeNTo et al. 2007) and A. mahalpa (SРеCHT et al. 2008).

The length and width of $A$. malefida pupae (Table $\mathrm{V}$ ) were similar to those obtained by Rizzo et al. (1995) and greater than those described by ANGulo et al. (2008). The fact that female pupae were significantly larger and heavier than their male counterparts (Table V) was previously described as sexual dimorphism (e.g., Angulo et al. 2008).

\section{Biotic potential}

The biotic potential of $A$. malefida, $6.067 \times 10^{5}$ individuals per female, is very low when compared to the biotic potential of $A$. ipsilon, approximately $4.120 \times 10^{18}$ (calculated using the data from BENTo et al. 2007). Whereas, the fecundity and fertility of $A$. malefida is similar to A. ipsilon, the difference in the biotic potential of these two species was primarily a function of the difference between the life cycle and survival. The total duration of the life cycle of $A$. malefida (Table I) was three times longer than that of A. ipsilon (SANTOS \& NAKANO 1982, BENTO et al. 2007). Moreover, the total survival, especially of the prepupal stage of $A$. malefida (Table I), was much lower than described for A. ipsilon (HARRIs et al. 1962, SwIER et al. 1976, SANTOS \& NAKANo 1982, Bento et al. 2007).

\section{Life and fertility tables}

The net reproductive rate $(\mathrm{Ro}=322.6)$, the intrinsic rate of increase $(\mathrm{rm}=0.24)$ and the finite rate of increase $(\Lambda=1.27)$ are lower than those obtained for A. ipsilon by BENTO et al. (2007), who reported a Ro of 616.9, a rm of 0.94 and a $\Lambda$ of 2.55 . Similar to what was observed in biotic potential, and considering the high fertility of $A$. malefida obtained in this study, the discrepancy between our results and those mentioned above can be explained by the shorter generation time of A. ipsilon $(\mathrm{T}=$ 6.86 weeks), when compared to $A$. malefida ( $\mathrm{T}=23.97$ weeks).

\section{Final considerations}

Although Angulo \& Quezada (1975) observed morphological and behavioral similarities between adults of $A$. malefida and $A$. ipsilon, our results demonstrated that the life cycle of both species are very different, being longer in A. malefida.

Our results demonstrated that in warmer regions, especially at lower latitudes, A. malefida develops more than one generation per year, and adults can be collected throughout the year (Lafontaine 2004). However, as mentioned by Bentancourt \& SCATONI (2006), in temperate regions and at higher latitudes, this species, like other representatives of Noctuidae, goes through larval (prepupa) and pupal diapause (Honì 1979, WILson et al. 1979, OKu 1984, FANTinou et al. 1996, GADENNe et al. 1997, QURESH et al. 2000, Feng et al. 2010, Eizaguirre et al. 2008). The occurrence of larval and/or pupal diapause highlights the need to 
develop further studies in order to assess the response of $A$. malefida to environmental variations such as photoperiod, humidity, temperature or combinations thereof.

The observation that $A$. malefida goes through diapause indicates that other species with similar distribution and occurrence such as Agrotis brachystria (Hampson, 1903) and Agrotis gypaetina Guenée, 1852 (SPECHT et al. 2004, Bentancourt \& SCATONI 2006) may also present this type of physiological behavior.

Considering the widespread distribution and its easy development in the laboratory, $A$. malefida could be a good model for biological studies, especially for comparing species that exhibit different behaviors depending on the latitude in which they live.

\section{ACKNOWLEDGMENTS}

This research was supported by the Conselho Nacional de Desenvolvimento Científico e Tecnológico (CNPq).

\section{LITERATURE CITED}

Allen, C.E.; B.J. Zwana \& P.M. Brakefield. 2011. Evolution of sexual dimorphism in the Lepidoptera. Annual Review of Entomology 56: 445-464.

Angulo, A.O. \& A.E. QueZada. 1975. Agrotis ipsilon (Hüfnagel) y Feltia malefida (Guenee): Aspectos ecologicos y evolutivos de dos especies de noctuidos similares en el mundo (Lepidoptera: Noctuidae). Boletín de la Sociedad Biológica de Concepción 49: 117-124.

Angulo, A.O.; T.S. Olivares \& G.T. Weigert. 2008. Estados inmaduros de lepidópteros nóctuidos de importancia agrícola y forestal en Chile y claves para su identificación (Lepidoptera: Noctuidae). Concepción, Universidad de Concepción, $3^{\text {rd }}$ ed., $154 \mathrm{p}$.

Archer, T.L.; G.L. Musick \& R.L. Murray. 1980. Influence of temperature and moisture on black cutworm (Lepidoptera: Noctuidae) development and reproduction. The Canadian Entomologist 112: 665-673.

BAUdino, E. 2004. Presencia y distribución temporal del complejo de orugas cortadoras (Lepidoptera: Noctuidae) en pasturas de alfafa (Medicago sativa L.) del área fisiográfica Oriental de la provincia de La Pampa, Argentina. Revista de la Facultad Agronomía - Universidad Nacional de La Pampa 15: 31-42.

Baudino, E. \& D. Villarreal. 2007. Orugas cortadoras que dañan cultivos de cosecha gruesa y pasturas de alfalfa en la región oriental de la provincia de La Pampa. Revisión bibliográfica. Revista de la Facultad Agronomía - Universidad Nacional de La Pampa 18: 11-57.

Bentancourt, C.M. \& I.B. Scatoni. 2006. Lepidópteros de importancia económica en Uruguay - Reconocimiento, biología y daños de las plagas agrícolas y forestales. Buenos Aires, Editorial Hemisferio Sur, $2^{\text {nd }}$ ed., 437p.
Bento, F.M.M.; S.R. Magro; P. Fortes; N.G. Zério \& J.R.P. Parra. 2007. Biologia e tabela de vida de fertilidade de Agrotis ipsilon em dieta artificial. Pesquisa Agropecuária Brasileira 42: 1369-1372.

Coto, D.; J.L. SAunders; C.L. VARgas-S \& A.B.S. King. 1995. Plagas invertebradas de cultivos tropicales con énfasis em América Central - Um inventário. Turrialba, CATIE, 200p.

Eizaguirre, M.; C. López \& R.C. Albajes. 2008. Factors affecting the natural duration of diapause and post-diapause development in the Mediterranean corn borer Sesamia nonagrioides (Lepidoptera: Noctuidae). Journal of Insect Physiology 54: 1057-1063.

Esperk, T.; T. Tammaru \& S. Nylin. 2007. Intraspecific variability in number of larval instars in insects. Journal of Economic Entomology 100: 627-645.

Fantinou, A.A.; J.A. TsitsipIs \& M.G. Karandinos. 1996. Effects of short- and long-photoperiods on growth and development of Sesamia nonagrioides (Lepidoptera: Noctuidae). Environmental Entomology 25: 1337-1343.

Feng, H.; F. Gould; Y. Huang; Y. Jiang \& K. Wu. 2010. Modeling the population dynamics of cotton bollworm Helicoverpa armigera (Hübner) (Lepidoptera: Noctuidae) over a wide area in northern China. Ecological Modeling 221: 1819-1830.

FoERSTER, L.A. \& M.E.F. Mello. 1996. Desenvolvimento e sobrevivência de Anicla infecta Guenée (Lepidoptera: Noctuidae) em diferentes temperaturas. Anais da Sociedade Entomológica do Brasil 25: 33-38.

Gadenne, C.; M.-C. Dufour; F. Rossignol; J. Becard \& F. Couillaud. 1997. Occurrence of non-stationary moults during diapause in the corn-stalk borer, Sesamia nonagrioides (Lepidoptera: Noctuidae). Journal of Insect Physiology 43: 425-431.

Greene, G.L.; N.C. Leppla \& W.A. Dickerson. 1976. Velvetbean caterpillar: a rearing procedure and artificial medium. Journal of Economic Entomology 69: 487-488.

Harris, C.R.; J.H. Mazurek \& G.V. White. 1962. The life history of Black Cutworm, Agrotis ipsilon (Hufnagel) under controlled conditions. The Canadian Entomologists 94: 1183-1187.

Honk, A. 1979. Regulation of diapause, number of instars, and body growth in the moth species Amathes c-nigrum (Lepidoptera: Noctuidae). Entomologia Generalis 5: 221-229.

Igarzábal, D.; P. Fichetti \& M. Tognelli. 1994. Claves prácticas para la identificación de larvas de Lepidoptera en cultivos de importancia agrícola en Córdoba (Argentina). Gayana Zoológica 58: 99-142.

Kitching, I.J. \& J.E. Rawlins. 1998. 19 - The Noctuoidea, p. 355401. In: Kristensen, N.P. (ed.). Lepidoptera, Moths and Butterflies vol. 1: Evolution, Systematics and Biogeography. Berlin, Walter de Gruyter, 491p.

Lafontaine, J.D. 2004. Noctuoidea, Noctuinae, Agrotini. In: R.W. Hodges; D.R. Davis; D.C. Ferguson; E.G. Munroe \& J.A. Powell. (Eds). The moths of America North of Mexico. Lawrence, Allen Press, Fasc 25-1, 385p. 
Lafontaine, J.D. \& B.C. Schmidt. 2010. Annotated check list of the Noctuoidea (Insecta, Lepidoptera) of North America north of Mexico. ZooKeys 40: 1-239.

López, C.; M. Eizaguirre \& R.A. Albajes. 2003. Courtship and mating behavior of the Mediterranean corn borer, Sesamia nonagrioides (Lepidoptera: Noctuidae). Spanish Journal of Agricultural Research 1: 43-51.

Margheritis, A. \& H. Rizzo. 1965. Lepidópteros de interés agrícola. Buenos Aires, Editorial Sudamericana, 197p.

Montezano, D.G.; A. Specht; T.M. Bortolin; E. Fronza; D.R. SosaGómez; V.F. Roque-Specht; P. Pezzi; P.C. Luz \& N.M. Barros. 2013. Immature stages of Spodoptera albula (Walker) (Lepidoptera: Noctuidae): Developmental parameters and host plants. Anais da Academia Brasileira de Ciências 85: 271-284.

Moreno Fajardo, M.L. \& F.J. Serna Cardona. 2006. Biología de Peridroma saucia (Lepidoptera: Noctuidae: Noctuinae) en flores cultivadas del híbrido comercial de Alstroemeria spp. Revista de la Facultad Nacional de Agronomía - Medellín 59: 3435-3448.

Окч, Т. 1984. Larval diapause in the spotted cutworm, Xestia cnigrum Linné (Lepidoptera: Noctuidae). Applied Entomology and Zoology 19: 483-490.

PASTRANA, J.A. 2004. Los lepidópteros argentinos: sus plantas hospedadoras y otros sustratos alimenticios. Buenos Aires, Sociedad Entomológica Argentina, 350p.

Pastrana, J.A. \& J.O. Hernandez. 1979. Clave de orugas de lepidópteros que atacan al maíz en cultivo. Revista de Investigaciones Agropecuarias (INTA), Serie 5, Patología Vegetal 14: 13-45.

Pogue, M. 2006. The Noctuinae (Lepidoptera: Noctuidae) of Great Smoky Mountains National Park, U.S.A. Zootaxa 1215: 1-95.

Poole, R.W. 1989. Noctuidae, p. 501-1013. In: J.B. Heppner (Ed). Lepidopterorum Catalogus. New York, Brill, vol. 2.

Qureshi, M.H.; T. Murai; H. Yoshida \& H. Tsumuki. 2000. Populational variation in diapause-induction and -termination of Helicoverpa armigera (Lepidoptera: Noctuidae). Applied Entomology and Zoology 35: 357-360.

Reese, J.C.; L.M. English; T.R. Yonke \& M.L. Fairchild. 1972. A method for rearing Black Cutworms. Journal of Economic Entomology 65: 1047-1050.

Rizzo, H.F.; F.R. La Rossa \& A.M. Folcia. 1995. Aspectos Morfológicos y Biológicos del "Gusano Áspero" (Agrotis malefida (Guenée)) (Lep.: Noctuidae). Revista de la Facultad Agronomía - Universidad de Buenos Aires 15: 199-206.

SANTOS, H.R. \& O. NAKANO. 1982. Dados biológicos sobre a lagarta rosca Agrotis ipsilon (Hufnagel, 1776) (Lepidoptera, Noctuidae). Anais da Sociedade Entomológica do Brasil 11: 33-48.

SCHNEIDER, J.C. 2009. Environmental biology of insect rearing, p. 97120. In: J.C. SCHNEIDER (ed.). Principles and procedures for rearing high quality insects. Starkville, Mississippi State University.

Silva, A.G.A; C.R. Gonçalves; D.M. Galvão; A.J.L. GonÇalves; J. Gomes; M.M. Silva \& L. Simoni. 1968. Quarto catálogo dos insetos que vivem nas plantas do Brasil, seus parasitos e predadores. Rio de Janeiro, Ministério da Agricultura, Parte II, $1^{\circ}$ Tomo, 622p.

Silveira-Neto, S.; O. Nakano; D. Barbin \& N.A. Villa Nova. 1976. Manual de ecologia dos insetos. São Paulo, Editora Agronômica Ceres, 420p.

Specht, A. \& E. Corseuil. 1996. Lista documentada dos noctuídeos (Lepidoptera; Noctuidae) ocorrentes no Rio Grande do Sul, Brasil. Biociências 4: 131-170.

Specht, A. \& E. Corseuil. 2002. Diversidade dos noctuídeos (Lepidoptera, Noctuidae) em Salvador do Sul, Rio Grande do Sul, Brasil. Revista Brasileira de Zoologia 19: 281-298.

Specht, A.; E.J.E. Silva \& D. Link. 2004. Noctuídeos (Lepidoptera, Noctuidae) do Museu Entomológico Ceslau Biezanko, Departamento de Fitossanidade, Faculdade de Agronomia "Eliseu Maciel", Universidade Federal de Pelotas, RS. Revista Brasileira de Agrociências 10: 389-409.

Specht, A.; J.A. Teston; R.A. Di Mare \& E. Corseuil. 2005. Noctuídeos (Lepidoptera, Noctuidae) coletados em quatro Áreas Estaduais de Conservação do Rio Grande do Sul, Brasil. Revista Brasileira de Entomologia 49: 130-140.

Specht, A.; A.C. Formentini \& E. Corseuil. 2006. Biologia de Hylesia nigricans (Berg) (Lepidoptera, Saturniidae, Hemileucinae). Revista Brasileira de Zoologia 23: 248-255.

Specht, A.; A.C. Formentini \& E. Corseuil. 2008. Bionomy of Anicla mahalpa Schaus, 1898 (Lepidoptera: Noctuidae: Noctuinae), in the laboratory. Brazilian Journal of Biology 68: 415-418.

Swier, S.R.; R.W. Rings \& G.J. Musick. 1976. Reproductive behavior of the black cutworm Agrotis ipsilon. Annals of the Entomological Society of America 69: 546-550.

TaRraGó, M.F.S.; S. Carvalho \& D. Link. 1975. Levantamento da família Noctuidae, através de armadilha luminosa, em Santa Maria, RS. Revista do Centro de Ciências Rurais 5: 125-130.

Teston, J.A.; A. Specht \& E. Corseuil. 2001. Biology of Anicla infecta (Ochsenheimer, 1816) (Lepidoptera, Noctuidae, Noctuinae), under laboratory conditions. Brazilian Journal of Biology 61: 661-666.

Villata, C.A.; M.R. Limonti \& S.R. Castellano. 1988. Estudio biológico de Agrotis malefida (Guen.). Revista Agropecuaria de Manfredi y Marcos Juárez 4: 37-51.

Wilson, A.G.L.; T. Lewis \& R.B. Cunningham. 1979. Overwintering and spring emergence of Heliothis armigera (Hübner) (Lepidoptera: Noctuidae) in the Namoi Valley, New South Vales. Bulletin of Entomological Research 69: 97-109.

ZagatTI, P.; B. LalanNe-Cassou \& J.D. D'Aubigny. 2006. Catalogue of the Lepidoptera of the French Antilles. Institut National de la Recherche Agronomique. Availble online at: http:// www.inra.fr/papillon/noctuid/noctuin/texteng/a_malefi.htm [Accessed: 14/XII/2012]

Submitted: 27.XI.2012; Accepted: 28.XII.2012.

Editorial responsibility: Gabriel L.F. Mejdalani 